\title{
Electrophysiology and colour perimetry in dominant infantile optic atrophy
}

Max-Planck Institute for Clinical and Physiological Research, Parkstrasse 1, 6350 Bad Nauheim, Federal Republic of Germany

T A Berninger

Universitäts-Augenklinik, Mathildenstrasse 8, 8 München 2, FRG

T A Berninger

Universitäts-Augenklinik, 6900 Heidelberg, FRG

W Jaeger

H Krastel

Correspondence to:

Dr T A Berninger.

Accepted for publication

5 July 1990

T A Berninger, W Jaeger, H Krastel

\begin{abstract}
A typical finding in dominant infantile optic atrophy (DIOA) is the variation of the phenotypic expression of the DIOA gene even within one family. It is of special interest for genetic. consultation to evaluate an examination method for detecting subclinically involved patients. Seven patients of two families were examined. Three of them had the typical symptoms of DIOA: reduced visual acuity, tritan defect, temporal pallor of both optic discs, and a relative central scotoma for white test spots. In visual evoked cortical potentials (VECP) the amplitudes were reduced, and in one patient the latencies were slightly delayed and two patients considerably so. The amplitude of the negative component of the PERG was markedly reduced, while the positive component was normal. In the remaining four family members normal retinal and cortical responses were recorded under standard conditions and visual fields and colour vision (FM 100 hue) were also normal. However, static perimetry with blue test spots showed in two family members enlarged central scotomas, thus proving that they had subclinical DIOA.
\end{abstract}

A tritan defect forms the decisive diagnostic clue to most cases of dominant infantile optic atrophy (DIOA). ${ }^{1-4}$ François $^{5}$ and Verriest ${ }^{6}$ found that the colour arrangement tests are particularly suitable for discovering such acquired tritan defects. In particular the desaturated Panel D15 has proved to be successful in the early detection of tritan defects in dominant optic atrophy. ${ }^{7}$

These findings are inconsistent with Koellner's rule that lesions of the receptor and bipolar retinal layers cause loss of blue-yellow sensitivity and that lesions of the ganglion cells and pregeniculate pathways affect red-green. ${ }^{8}$ Histological findings, however, identified the retinal ganglion cells as the site of primary damage in DIOA. ${ }^{910}$ Further, it is striking that the phenotypic expression of the DIOA gene varies even within a family, ${ }^{11-13}$ ranging from severely affected patients who have both red-green and blue-yellow defects ${ }^{74}$ to those scarcely affected in whom not even a tritan defect can be observed. Visual fields tested in the usual clinical manner frequently show only mild abnormalities or at times appear normal. ${ }^{15}$ Even the optic nerve may show only questionable pallor or appear normal in some individuals. ${ }^{12}$ Krill $e t a l^{12}$ therefore recommended that an experienced ophthalmologist should examine the optic nerve head so that subtle changes might also be detected.

The aim of this study was the evaluation of methods for detecting subclinical involved patients with DIOA.
Patients and methods

Two families (family A: five members; family B: two members) were examined. We recorded the best corrected visual acuity and the results of slitlamp biomicroscopy, Tübinger automatic perimetry (TAP) (family A), the Goldmann visual field test (family B), the FarnsworthMunsell 100-hue test (A2, A3, A4, A5), the Panel D-15 desaturated test (A1, B1, B2), funduscopy, pattern reversal evoked cortical potentials (VECP), and pattern reversal electroretinogram (PERG) tests.

VISUAL EVOKED CORTICAL POTENTIALS (VECP)

The standard conditions for the VECP were as follows: Checkerboard pattern stimuli were generated on a black-and-white TV monitor. The field size of the screen subtended $14.5^{\circ}$ by $18.5^{\circ}$ and the checks were $38 \mathrm{~min}$ of arc. The mean luminance was $30 \mathrm{~cd} / \mathrm{m}^{2}$ and the modulation depth was 0.97 . The checks were temporally alternated at a modulation rate of four reversals $/ \mathrm{s}$ $(2 \mathrm{~Hz})$. The active electrode was attached $2-3 \mathrm{~cm}$ above the inion. The right ear was earthed and the reference electrode fixed to the left ear. All VECP recordings were monocular. In some cases the mean luminance was reduced to $10 \mathrm{~cd} / \mathrm{m}^{2}$ and the modulation depth to $0 \cdot 2$ (reduced contrast test).

\section{PATTERN ELECTRORETINOGRAM (PERG)}

Arden gold foil electrodes were used. ${ }^{16}$ The reference electrode was placed on the ipsilateral temple, thus minimising retinal and cortical contamination. ${ }^{1718}$ The stimulus was provided by a checkerboard pattern reversal on a TV screen of $14.5^{\circ}$ by $18 \cdot 5^{\circ}$. The visual angle of each square was $50 \mathrm{~min}$ of arc, modulation depth 0.97 , reversing rate $4 \mathrm{rev} / \mathrm{s}(2 \mathrm{~Hz})$.

Retinal and cortical potentials were amplified by a Medelec AA6 with bandpass setting $0 \cdot 16$ and $32 \mathrm{~Hz}$ and averaged by a Nicolet 1170 . Four samples of 64 sweeps were used to obtain the final result.

\section{COLOUR VISUAL FIELD}

With the Tübinger automatic perimeter (TAP) ${ }^{19}$ white and blue test spots of $0.16^{\circ}$ diameter were presented for $200 \mathrm{~ms}$. Yellow adaptation (Schott OG $530 \mathrm{~nm}$ cutoff filter) was applied to isolate the activity of the blue system. Luminance distribution was adjusted to compensate for the loss of sensitivity towards the periphery (for details see Krastel $e t a l^{20}$ ). A small foveal scotoma was obtained for normal subjects using blue test spots, which is due to the foveal tritanopia. ${ }^{21}$ 
Figure 1 Visual evoked cortical potentials are shown. On the left are the recordings with high contrast and on the right those with low contrast. Note that for high contrast all three family members of patient (A3) have a normal $\operatorname{VECP}(A 2, A 4, A 5)$, while for low contrast two patients $(A 2, A 5)$ have a slightly increased P100 latency above $2 S D$.
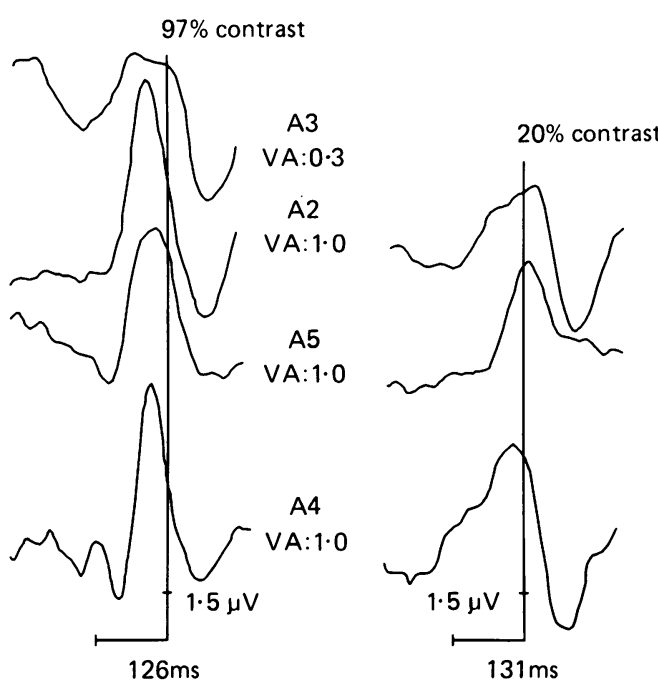

COLOUR VISION

Colour vision was tested by Farnsworth-Munsell 100-hue, Panel D-15 desaturated test, tritanomaloscopy, and spectral increment thresholds.

\section{Results}

VISUAL EVOKED CORTICAL POTENTIALS

The visual evoked potentials were only abnormal in the severely affected patient (A3, B1, B2) (Fig 1). In $B 1$ and $B 2$ a positive-negative-positive (PNP) complex was observed. In contrast, patient A3 had a broad positive deflection with only a slight delay of the P-100 latency.

\section{PATTERN ELECTRORETINOGRAM}

PERGs were obtained in all patients. Normal positive components were measured in all seven patients. The negative components of the patients $\mathrm{A} 1, \mathrm{~A} 2, \mathrm{~A} 4$, and $\mathrm{A} 5$ were also in the normal range. However, a significantly reduced negative component was found in three other patients (A3, B1, B2) with definite DIOA.

COLOUR VISUAL FIELD

The visual fields of both members of family B were tested with a Goldmann perimeter. A

L

$\partial \mathrm{I}$

2.

sil. il

"( TAT

Figure 2 Pattern electroretinograms of four patients ( $A 2, A 3, A 5, B 1)$ are shown. Note that the two subclinically involved patients (A2, A5) have normal positive and negative PERG components, while hardly any negative PERG component was recorded for the severely affected patients $(A 3, B 1)$. central scotoma was found in both patients. All

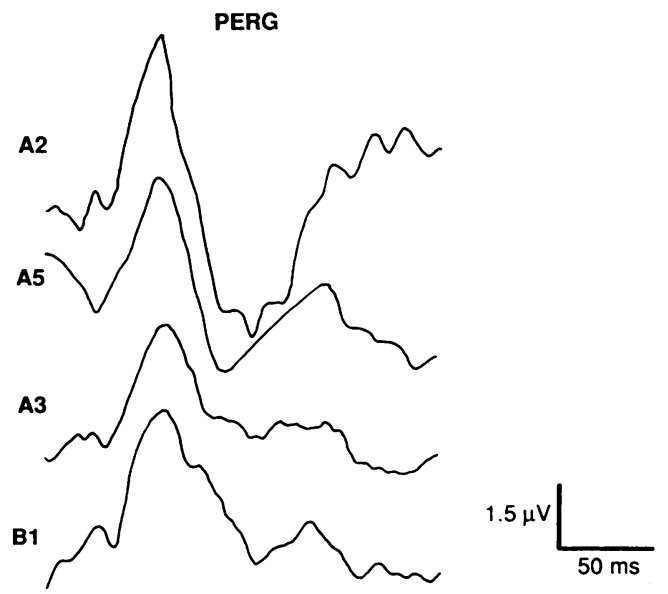

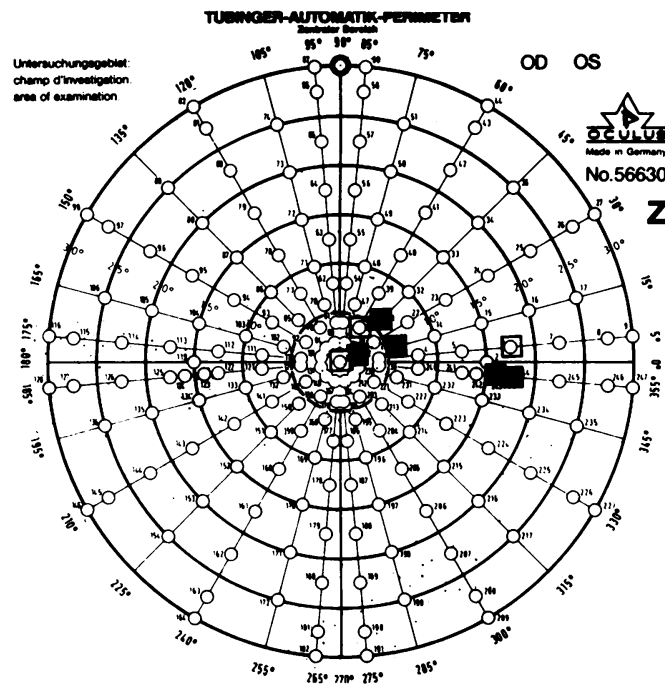

Figure 3 Normal static perimetry fields for white test spots is shown for patient ( $A 5)$.

members of family A were tested with the TAP. With the white test spot a central scotoma was observed only in patient A3. His father (A1) and his eldest sister (A4) also had a normal visual field for blue test spots, but the mother (A2) and the younger sister (A5) both had an enlarged central scotoma (Figs 3 and 4).

\section{COLOUR VISION}

Four patients (A2, A3, A4, A5) were tested with the Farnsworth Munsell 100-hue test and three (A1, B1, B2) with the Panel D-15. Colour arrangement tests detected an obvious defect only in those patients (A3, B1, B2) who showed significant signs of the disease. However, we observed one obligate and one possible carrier of the gene, who according to the conventional tests (visual acuity, colour arrangement, white perimetry) seemed to be not involved. For reasons of colour perimetry (see Discussion) we regarded these patients (A2, A5) as subclinically affected. The results of the tritanomalscopy and spectral sensitivity are published elsewhere. ${ }^{22}$

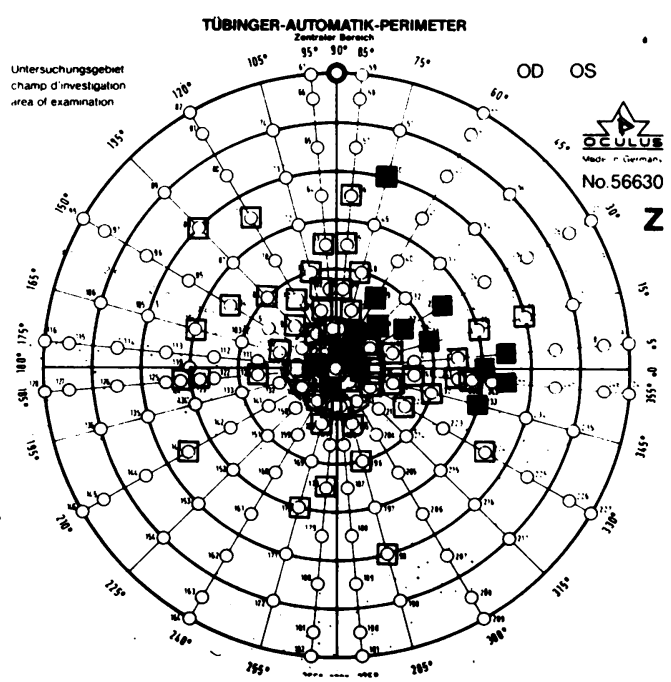

Figure 4 Static perimetry field for blue test spots is shown for patient (AS). A large central scotoma is present, while the visual field for white test spots was normal (see Fig 3). 
Table 1 Patients examined by static perimetry and blue test targets

\begin{tabular}{|c|c|c|c|c|c|c|c|c|}
\hline \multirow[b]{2}{*}{ Pat. } & \multirow[b]{2}{*}{ Sex } & \multirow[b]{2}{*}{ Age } & \multicolumn{2}{|l|}{$V A$} & \multirow[b]{2}{*}{ Optic disc } & \multirow[b]{2}{*}{$F-100$} & \multicolumn{2}{|l|}{ Perimetry } \\
\hline & & & $R E$ & $L E$ & & & White & Blue \\
\hline $\begin{array}{l}\text { A1 } \\
\text { A2 } \\
\text { A3 } \\
\text { A4 } \\
\text { A5 } \\
\text { B1 } \\
\text { B2 }\end{array}$ & $\begin{array}{l}M \\
F \\
M \\
F \\
F \\
M \\
M\end{array}$ & $\begin{array}{l}74 \mathrm{yr} \\
65 \mathrm{yr} \\
37 \mathrm{yr} \\
34 \mathrm{yr} \\
30 \mathrm{yr} \\
42 \mathrm{yr} \\
18 \mathrm{yr}\end{array}$ & $\begin{array}{l}1 \cdot 0 \\
1 \cdot 0 \\
0 \cdot 3 \\
1 \cdot 0 \\
1 \cdot 0 \\
0 \cdot 2 \mathrm{p} \\
0 \cdot 3 \mathrm{p}\end{array}$ & $\begin{array}{l}1 \cdot 0 \\
0 \cdot 8 \\
0 \cdot 3 \\
1 \cdot 0 \\
1 \cdot 0 \\
0 \cdot 2 \mathrm{p} \\
0 \cdot 3 \mathrm{p}\end{array}$ & $\begin{array}{l}\text { Normal } \\
\text { ?Temp. palor } \\
\text { Temp. pallor } \\
\text { Normal } \\
\text { ?Temp. pallor } \\
\text { Temp. pallor } \\
\text { Temp. pallor }\end{array}$ & $\begin{array}{l}\text { D-15 Normal } \\
118(-180) \\
504(-108) \\
24(-108) \\
88(-92) \\
\text { Tritan } \\
\text { Tritan }\end{array}$ & $\begin{array}{l}\text { Normal } \\
\text { Normal } \\
\text { CS } \\
\text { Normal } \\
\text { CS } \\
\text { CS } \\
\text { CS }\end{array}$ & $\begin{array}{l}\text { Normal } \\
\text { CS } \\
\text { CS } \\
\text { Normal } \\
\text { CS } \\
- \\
-\end{array}$ \\
\hline
\end{tabular}

$\mathrm{VA}=$ Visual acuity. $\mathrm{CS}=$ central scotoma. ?Temp. pallor=questionable temporal pallor.

\section{Discussion}

The aim of this study was to find a diagnostic clue for detecting subclinical involvement in DIOA. We first studied severely affected patients to determine the precise changes in patients with DIOA.

\section{VISUAL EVOKED CORTICAL POTENTIALS}

Harding et $a l^{23}$ and Crews and Harding ${ }^{24}$ observed a positive-negative-positive (PNP) response (negativity around $100 \mathrm{~ms}$ ) in most patients with DIOA. The characteristic PNP complex was more commonly seen with flash stimuli. It is not yet clear whether this triphasic PNP response is generated by a negative replacement of the positive P100 (P2) component. We recorded the flash VECP only in one patient $(\mathrm{B} 1)$ and did not find the PNP complex. However, using pattern reversal stimuli we observed the PNP complex in two patients (B1, B2), while in one patient (A3) a broad deflection with only a slight delay was found. The broad envelope of the response suggests that, while some neural elements have more or less retained their function, others are more seriously affected. It should be remarked that the visual acuity was more impaired in the patients (B1, B2) in whom the amplitudes of VECP were more reduced and the PNP complex appeared. In patients with more severe visual impairment Kline and Glaser ${ }^{25}$ recorded diminished amplitudes and prolonged latencies, consistent with neural conduction defects. These observations support the idea that the PNP complex might be a marked delay of the P100 components of the VECP. A follow-up study may evaluate whether all our patients develop a PNP in parallel with their decreasing visual acuity. However, it has to be noted that the recording technique of Harding $e t a l^{23}$ and Crews and Harding ${ }^{24}$ is different from ours and that of Kline and Glaser, ${ }^{25}$ which may also explain the different findings.

It is believed that in DIOA contrast processing is particularly affected. ${ }^{26}$ Since we observed normal P100 latency in all four family members using high modulation depth $(0.97)$, we reduced the modulation depth to 0.2 and the mean luminance to $10 \mathrm{~cd} / \mathrm{m}^{2}$. We expected that this stimulus would be close to the threshold of the slightly altered ganglion cells of the patients subclinically involved. However, the delay seen in two patients (A2, A5) was between 2 and 3 standard deviations of a normal mean value (Fig 1).

PATTERN ELECTRORETINOGRAM

The PERG has at least two components: an early positive component which is not specific to changes in retinal distribution of contrast, followed by a negative wave showing spatial tuning across temporal frequency. ${ }^{27}$ Recently Holder ${ }^{28}$ observed that the positive component of the PERG is reduced in macula diseases while in optic nerve disease the negative component of the PERG is selectively decreased, and this has been confirmed..$^{29} \mathrm{DIOA}$ is a clear-cut case of damage confined to the optic nerve, and our findings in the patients $A 3, B 1$, and $B 2$ thus strengthen the claim that the negative PERG component is affected in optic nerve defects. Papst $e t a l^{30}$ observed a normal positive component of the PERG in their patients, as we did in cases (A3, B1, B2). However, again normal results were obtained for our subclinically involved family members (Fig. 2).

\section{COLOUR VISUAL FIELD}

Testing the visual field with a coloured target is not a new method. A paradoxical phenomenon has been observed in DIOA patients in kinetic perimetry: since the perception for blue targets is poorer than for red targets, the red field is larger than the blue (red-blue inversion). ${ }^{31-37}$ Static perimetry, however, is more sensitive than kinetic perimetry for detecting small field defects and relative scotomas. ${ }^{4172038}$

Therefore we examined the patients by static perimetry and blue test targets, thus obtaining a much higher sensitivity of the visual field test. We could then detect a central scotoma for blue test targets in subclinically involved patients (A2, A5), while visual acuity, FM 100-hue, and visual field tests for white targets are still normal (Table 1).

The authors thank Professor Dr E Dodt for his continuous support and the helpful discussions. They are further indebted to Professor G B Arden for help with the manuscript.

1 Jaeger W. Dominant vererbte Optikusatrophie (unter besonderer Berïcksichtigung der dabei vorhandenen Farbsinnstörungen). Graefes Arch Clin Exp Ophthalmol Farbsinnstörungen)

2 Lodberg CV, Lund A. Hereditary optic atrophy with dominant transmission. Three Danish families. Acto Ophthalmol (Kbh) 1950; 28: 437-49.

$3 \mathrm{Kjer}$ P. Congenital optic atrophy with dominant mode of inheritance: a clinical and genetic study of 19 Danish families. Acta Ophthalmol (Kbh) 1959; 37 (suppl): 54-145.

4 Grützner P. Über Diagnose und Funktionsstörungen bei der infantilen dominant vererbten Optikusatrophie. Ber Dtsch Ophthalmol Ges 1963; 65: 268-73.

5 Francois J. An acquired deficiency of colour vision. Vision Res 1961; J. An aç

6 Verriest G. Further studies on acquired deficiency of color discrimination. F Opt Soc Am 1963; 53: 185-95.

7 Jaeger W, Boerner C, Boerner C. Verlaufsbeobachtungen der Farbsinnstörung (Tritandefekt) bei dominanter infantiler Optikusatrophie. In: Herzau von, ed. Pathophysiologie des Sehens. Stuttgart: Enke, 1984: 87-95.

8 Koellner H. Die Störung des Farbsinnes, ihre Bedeuting und ihre Diagnose. Berlin: Karger, 1912.

9 Johnston PB, Gaster RN, Smith VC, Tripathi RC. A clinicopathological study of autosomal dominant optic atrophy. Am $\mathcal{F}$ Ophthalmol 1979; 88: 868-75.

10 Kjer P, Jensen OA, Klinken L. Histopathology of eye, optic nerve and brain in a case of dominant optic atrophy. Acto Ophthalmol (Kbh) 1983; 61: 300-12.

11 Grützner P. Über erworbene Farbsinnstörungen bei Sehnervenerkrankungen. Graefes Arch Clin Exp Ophthalmo Sehnervenerkrank

12 Krill AE, Smith VC, Pokorny. Similarities between congenital tritan defects and dominant optic-nerve atrophy: coincidtritan defects and dominant optic-nerve atroph
ence or identity? f Opt Soc Am 1970; 60: 1132-9.

13 Jaeger W. Dominant hereditary optic atrophy and Leber's disease. Doc Ophthalmol Proc Ser 1978; 17:91-115.

14 Krill AE, Smith VC, Pokorny J. Further studies supporting the identity of congenital tritanopia and hereditary dominan optic atrophy. Invest Ophthalmol Vis Sci 1971; 10: 457-65. 
15 Smith DP. Diagnostic criteria in dominantly inherited juvenile optic atrophy: a report of three new families. Am f Optom Physiol Opt 1977; 49: 183-200.

16 Arden GB, Carter RM, Hogg CR, Siegel IM, Margolis S. A gold foil electrode: extending the horizons for clinical electroretinography. Invest Ophthalmol Vis Sci 1979; 18: $421-6$.

17 Hess RF, Baker CL. Human pattern-evoked electroretinogram. F Neurophysiol 1984; 51: 939-51.

18 Berninger TA. The pattern electroretinogram and its contamination. Clin Vision Sci 1986; 1: 185-90.

19 Aulhorn E, Durst W. Rasterperimetrie in der augenärztlichen Praxis. Fortschr Ophthalmol 1982; 79: 350-3.
Plarn

20 Krastel H, Jaeger W, Braun S. Rasterperimetrie mi Farbreizen. Fortschr Ophthalmol 1986; 83: 690-701.

21 Williams DR, MacLeod DIA, Hayhoe MM. Foveal tritanopia. Vision Res 1981;21: 1341-75.

22 Jaeger W, Berninger TA, Krastel H. Pathophysiologica considerations in dominant optic atrophy based upon spectral sensitivity, tritan spectral sectionetry and deficiencies VIII. Dordrecht: Martinus Nijhoff/Dr W Junk, deficiencies VIII.
1987: $397-411$.

23 Harding GFA, Crews SJ, Pitts M. Psychophysical and visual evoked potential findings in hereditary optic atrophy. Trans Ophthalmol Soc UK 1979;99:96-102.

24 Crews SJ, Harding GFA. Visual evoked potentials and psychophysical findings in dominant hereditary optic atrophy. Doc Ophthalmol Proc Ser 1981; 27: 167-74.

25 Kline LB, Glaser JS. Dominant optic atrophy: the clinical profile. Arch Ophthalmol 1979; 97: 1680-6.

26 Jaeger W, Krastel H. Degenerative Erkrankungen des Nervus opticus. In: Lund OE, Waubke TN, eds. Degenera- tive Erkrankungen des Auges. Stuttgart: Enke, 1983: 151-60. 27 Berninger TA, Schuurmans RP. Spatial tuning of the pattern ERG across temporal frequency. Doc Ophthalmol 1985; 61 : $17-25$.

28 Holder GE. Significance of abnormal pattern electroretinography in anterior visual pathways dysfunction. $\mathrm{Br} \mathcal{F}$ Ophthalmol 1987; 71: 166-71.

29 Ryan S, Arden GB. Electrophysiological discrimination between retinal and optic nerve disorder. Doc Ophthalmol between retinal

30 Papst N, Bopp M, Wundrack ĖM. Muster-ERG und MusterVECP bei autosomal dominanter infantiler Optikusatrophie. Fortschr Ophthalmol 1985; 82: 300-1.

31 Scott JG. Hereditary optic atrophy with dominant transmission and early onset. BrF Ophthalmol 1941; 25: 461-79.

32 Iverson HA. Hereditary optic atrophy. Arch Ophthalmol 1958; 59: 850-3.

33 Ruby J, Davey JB. Dominantly inherited optic atrophy. $\mathrm{Br} \mathcal{F}$ Ophthalmol 1958; 42: 413-24.

34 Grehn F, Kommerell G, Ropers HH, Giesing B. Dominant optic atrophy with sensorineural hearing loss. Ophthalmic Paediat Genet 1982; 1: 77-88.

35 Ohba N, Inamura PM, Tanino T. Colour vision in a pedigree with autosomal dominant optic atrophy. Mod Probl Ophthalmol 1976; 17: 315-9.

36 Caldwell JBH, Howard RO, Riggs LA. Dominant juvenile optic atrophy: a study in two families and review of hereditary disease in childhood. Arch Ophthalmol 1971; 85: 133-47.

37 Hoyt CS. Autosomal dominant opticus atrophy: a spectrum of disability. Ophthalmology 1980; 87: 245-51.

38 Verriest G. Further studies on acquired deficiency of colour vision. F Opt Soc Am 1963; 53: 185-95. 